\title{
A WINDOW INTO THE SOUL OF INTERNATIONAL ARBITRATION: ARBITRATOR SELECTION, TRANSPARENCY AND STAKEHOLDER INTERESTS
}

\section{Catherine Rogers*}

\author{
New Zealand Law Foundation International Dispute Resolution Lecture 2013, delivered at Stone \\ Lecture Theatre, University of Auckland Faculty of Law, 26 November 2013. This essay derives \\ from that lecture, which considers the important issue of arbitrator selection, appointment and \\ challenge standards and procedures, and introduces the Arbitrator Intelligence project - a \\ proposed solution for informational asymmetries that can affect the fairness of arbitrator selection \\ and appointment.
}

Thank you all for coming out on an evening after a workday. As is customary, I will begin by thanking only briefly the New Zealand Law Foundation, especially Crown Counsel Kristina Muller, for the kind invitation to come to this wonderful part of the world. I am also grateful to Professors Caroline Foster and Petra Butler for their organisational efforts, as well as the law faculties of both Victoria and Auckland, in particular the Dean, Andrew Stockley, for their hospitality.

I am going to save more extensive expression of my appreciation for the conclusion of this talk, as it relates to what I hope are some insights about what international arbitration might be looking forward to in the future in New Zealand.

This topic is uniquely important for those interested in dispute resolution. Selecting an arbitrator is the ultimate form of forum shopping. Ordinary forum shopping uses a particular venue as a proxy for features of the decision maker. Arbitrator selection eliminates the proxy, and allows for direct selection of the decision maker. This is obviously a critical moment in arbitration and goes to the

* Professor of Law and Price Family Scholar at Penn State Law; Professor of Ethics, Regulation and the Rule of law, Queen Mary, University of London. 
heart of fairness in the process. Fairness is a particular concern because the international arbitration community is growing dramatically, and newer and smaller players are joining constantly.

A good place to start is with the basics about how you select an international arbitrator.

In the typical arbitration, each party appoints an arbitrator and the two so-called "partyappointed arbitrators" select together, in one manner or another, the chairperson. Even if there is room for variation, that basic framework will be the background for the analysis that follows.

If a party has a dispute that involves arbitration, one of the first things the party will have to do is determine who would be a good party-appointed arbitrator for that dispute. That party will come up with a short list of potential arbitrators. This short list will be created based on their professional backgrounds, their legal training and their expertise.

Once a party has compiled a short list, it will gather information from "formal" and publicly available information, meaning from websites, from materials that arbitrators have published and other public sources. The problem with these ostensibly public sources is that they may only be available in a foreign system or in a language that is foreign to the party doing the research. Oftentime the international arbitration materials are very expensive. These practical and financial obstacles already foreshadow how information about arbitrators is not equally accessible to a smaller companies or newer parties.

Even if basic biographical information about arbitrators is readily available, more detailed information about how arbitrators actually decide cases is not. Arbitration awards typically are not publicly available (or if they are made public, the names of the arbitrators have most often been removed). Moreover, information about the case management skills and experience of arbitrators usually is obtained only though ad hoc individualised person-to-person inquiries. Given the stakes, it is a surprisingly low tech process with an inherently hit-or-miss quality.

Repeat players, meaning parties and counsel who have extensive experience in international arbitration, have access to prior awards in arbitrations in which they were a party, which for large law firms can number into the hundreds.

Meanwhile, some of the most valuable information is collected through individual, personal inquiries. But individuals' willingness to share sensitive information about arbitrators inevitably depends on how well they know or trust the person making the inquiry.

When asked about a particular arbitrator, as a matter of human nature, a friend or colleague will elicit much more detailed and nuanced insights about an arbitrator than a stranger will. As a consequence, opposing parties in the same arbitration could pose the same inquiry about the same candidate to the same person, but receive different responses! Arbitration insiders are much more likely to receive in-depth and sensitive insights because they are more likely to know personally others who have this information. 
In response to this situation, a number of people, both prominent arbitration insiders and some critics of international arbitration, have proposed eliminating party-appointed arbitrators. The problem, they contend, is that parties engage in intentional efforts to select their party-appointed arbitrators.

In this vein, Jan Paulsson, a tremendous figure in the international arbitration community, has caused some controversy by arguing that unilaterally appointed, party-appointed arbitrators - that is what he calls it - are ill-conceived, an unprincipled tradition and, in fact, a moral hazard. Get rid of them altogether, he argues. ${ }^{1}$

In a similar vein, another famous and esteemed international arbitrator, Albert Jan van den Berg, did a survey and found that overwhelmingly in investment arbitrations, party-appointed arbitrators dissent in favour of the party who appointed them, when they dissent.

There are some questions about his methodology. He concludes that nearly 100 per cent of the time, when party-appointed arbitrators dissent, they do so in a way that favours the party who appointed them. Others, including myself, have critiqued his research and suggested that instead the percentage might be closer to $80-85$ per cent. $^{2}$ Still, however, either number suggests systematic dissent in favour of the party who appoints a party-appointed arbitrator. For van den Berg, this systematic dissent reveals a deep problem.

There are still others, including Professor Gus Van Harten. In contrast to Paulsson and van den Berg, Professor Van Harten is one of the most strident critics of investment arbitration. In other words, Professor Van Harten almost never agrees with Messrs Paulsson and van den Berg on anything. But he does agree with them about eliminating party-appointed arbitrators. So we have, across the political spectrum, unique and vociferous support for the idea of eliminating partyappointed arbitrators.

Having reviewed the criticisms and concerns about party-appointed arbitrators, my goal now is instead to convince you that party-appointed arbitrators are an indispensable part of the structure of international arbitration and should be maintained. From there, I will suggest many implications, including how to make their appointment fairer.

Going back to Paulsson and van den Berg's critiques, they are primarily concerned with partisanship among party-appointed arbitrators. By contrast, I am more concerned about a potential dynamic called "groupthink".

1 Jan Paulsson "Moral Hazard in International Dispute Resolution" (2010) 25 ICSID Rev F Investment LJ 339 at 340 .

2 See Catherine A Rogers "The Politics and Empirics of Investment Arbitrators" (2013) 12 Santa Clara J Int'1 L 217 at 239. 
Groupthink is a theory that was developed by a scholar named Irving Janis back in the 1970s. ${ }^{3}$ He did not study international arbitration but when you hear details of his theory, you might almost believe he was.

"Groupthink" as a term has entered our modern lexicon, but back then it was really a new idea. Janis defined "groupthink" as a "mode of thinking that people engage in when they are deeply involved in a cohesive in-group, when the members' strivings for unanimity override their motivation to realistically appraise alternative courses of action". ${ }^{4}$ Groupthink "occurs when the decision-making capabilities of a panel become affected by subtle peer pressure". 5

Janis was not studying lawyers but instead how, for example, such bright foreign policy experts as those who advised President Kennedy could have concluded that the Bay of Pigs disaster was a good idea. His work has been used to examine boards of directors of major corporations, for example, to explain how a board of independent and intelligent directors at Enron could have gotten their decisions so wrong.

Janis's observations and findings have been echoed in more recent scholarship by Cass Sunstein who talks about social ties, suppressing dissent. ${ }^{6}$ And more locally and regionally an Australian professor, Stephen Bainbridge, who talks about highly cohesive groups with strong civility and cooperation norms perhaps not fully assessing alternatives. ${ }^{7}$ These are different articulations of the same idea of Groupthink.

Now, could Groupthink happen in international arbitration? Certainly the preconditions are there. Even Paulsson explains that some of the preconditions exist. He describes how leading arbitrators deliberate "within an intellectual zone of shared confidence". ${ }^{8}$ Meanwhile, in his study, van den Berg finds, depending on how you calculate it, that somewhere between 80-100 per cent of party-appointed arbitrators dissent in favour of the appointing party. ${ }^{9}$ That sounds like a terrible

3 Irving L Janis Victims of Groupthink: A Psychological Study of Foreign Policy Decisions and Fiascoes (Houghton Mifflin, New York, 1972) at 9.

4 At $9-10$.

5 At $9-10$

6 Jan Paulsson "Are Unilateral Appointments Defensible?" (2 April 2009) Kluwer Arbitration Blog <www.kluwerarbitrationblog.com>. See Cass R Sunstein "Deliberative Trouble? Why Groups Go to Extremes" (2000) 110 Yale LJ 71 at 85-86.

7 Stephen M Bainbridge "Why a Board? Group Decisionmaking in Corporate Governance" (2002) 55 Vand L Rev 1 at 32 .

8 See also Jason Webb Yackee "Controlling the International Investment Law Agency" (2012) 53 Harv Int'1 LJ 392 at 407 (the "small, relatively closed" investment arbitration "community is more likely to be relatively ideologically cohesive and better able to coordinate its policymaking efforts").

9 Rogers, above $\mathrm{n} 2$, at 239. 
statistic, right? Until you consider that party-appointed arbitrators only dissent in 22 per cent of cases. In other words, in 78 per cent of all cases he studied, tribunals reached a unanimous decision. When party-appointed arbitrators dissent, they dissent in favour of the party that appointed them. But it turns out that they don't dissent very often overall.

Various scholars - I could have a much longer list of people - have identified how the international arbitration community operates and benefits from an interconnectedness and an historically shared intellectual consensus. To some extent, the consensus is breaking down, particularly with respect to ethical norms and as a result of increased diversity among newcomers. But the ideological cohesion remains sufficiently robust to make the potential for groupthink real.

In addition to this intellectual environment, let me add a couple of features that may intensify the effect of the groupthink phenomenon in international arbitration. First, it is not an accident that arbitrators end up generally agreeing. There are actually articulated historical norms favouring unanimity in decision making.

In investment arbitration, we have about 22 per cent of the cases where there is a dissent, and a much smaller percentage in international commercial arbitration. Why? Because, in part, historically it was considered uncivilised to dissent in international arbitration. That history is part of why van den Berg is so concerned about what he sees as a crisis; a rise of dissenting opinions. Even if an apparently small rate of dissents overall, the 22 per cent occurrence seems unusual within the tradition of international arbitration.

Add to that background the fact that, in many international arbitration contexts and particularly in investment arbitration, there is an absence of firm legal constraints, meaning that the rules around which consensus is formed are ambiguous. As a result, arbitrators have a lot more flexibility in finding consensus, and there is no substantive review of the outcome they reach. In other words, if an arbitral tribunal finds itself consumed by groupthink, it will be largely unconstrained by law and with no one checking up on the substance if they got it wrong as a result of groupthink taking over more deliberative analysis.

Finally, an additional concern, at least for some, is that under some arbitral rules, arbitrators are compensated on a pro rata basis. The concern is that if an arbitrator is getting paid based on a percentage on the amount in dispute, there might be a financial incentive to do as little work as possible because any added hours invested won't earn any additional compensation for the arbitrator. That view is a little bit cynical, but it is certainly a possibility and some critics are convinced it represents an important temptation.

The good news is that Janis not only identified the problem of groupthink, he also prescribed a remedy. In response to a problem that is structural and integral to interpersonal group dynamics, the solution he proposes is similarly structural and integral. The most effective ways to reduce the prevalence of groupthink, according to Janis, is to insert into a tight-knit group certain individuals whose assigned function is to challenge the consensus of that group. 
The function of this person is to serve as what Janis calls the "devil's advocate", meaning someone who systematically and intentionally argues for a position contrary to whatever position is being advocated or contemplated within the group. Janis proposes that this role be formally designated and that the position be "rotate[d] among group members at each meeting". ${ }^{10}$

This is the justification, for example, for shareholder-nominated directors. Proponents of shareholder-nominated directors argue that they can break through groupthink because they have different interests and alliances than the other corporate officers on the board. Similarly, on an arbitral tribunal, arbitrators who are appointed by a party are essentially tasked with an obligation to look sceptically and question decisions by the other arbitrators when those decisions may have negative consequences for the party who appointed them.

In addition to the structural idea of a devil's advocate as a prophylactic against groupthink, Janis also offers what might be regarded as "style tips" for how devil's advocates should conduct themselves in order to be most effective. Janis suggests in fulfilling this "unambiguous assignment", the designated devil's advocate should "present arguments as cleverly and convincingly as [the person] can, like a good lawyer, challenging the testimony of those advocating the majority position". ${ }^{11}$ The devil's advocate, according to Janis, should ask tough questions and encourage suggestions in a low-key style, all while withholding his or her own opinion to avoid being too confrontational. ${ }^{12}$

These "style tips" from Janis about how to be a good devil's advocate are remarkably similar to admonitions about how to be a good party-appointed arbitrator. As many commentators have observed, a party-appointed arbitrator who acts overly aggressive or too overtly partisan will end up alienating other members of the tribunal and undermining their own ability to effectively influence the tribunal's decision making.

Anecdotal accounts are replete with stories of overly aggressive, overtly partisan partyappointed arbitrators who are ostracised, discounted or ignored on tribunals. In other words, referring back to famed arbitrator and scholar Martin Hunter's prescription, the optimal partynominated arbitrator is "someone with the maximum predisposition towards my client, but with the minimum appearance of bias". ${ }^{13}$

To borrow Janis' suggestion, the ideal party-appointed arbitrator is someone who can argue forcefully as a check against the majority's positions that are in opposition to those of the appointing

10 Janis, above $\mathrm{n} 3$, at 8 .

11 At 8 .

12 At 8

13 Martin Hunter "Ethics of the International Arbitrator" (1987) 53 Arb 219 at 223. 
party, but in a "low key" way that does not seem overtly partisan. By systematically but constructively second-guessing the majority, and expressly challenging it when appropriate, partyappointed arbitrators can improve the process, within tribunal deliberations, in the process of drafting the award and by, in some cases, actually writing a dissent.

Several commentators have offered anecdotal explanations of how party-appointed arbitrators contribute to deliberative functions on the tribunal. Most such explanations, however, are often offered by way of apology for historical practices or justification for a party's preferences. These accounts provide important real-world verification of the value of deliberations in which partyappointed arbitrators press against a groupthink-gravitational pull to the path of least resistance.

Under this view, party-appointed arbitrators are not a necessary evil that must be tolerated to make parties feel comfortable. They can be understood, instead, as an important structural feature of international arbitral tribunals. The threat and potential reality of publishing a dissent is part of this process of challenge that promotes accountability. It can also promote party confidence in a process that lacks any form of appellate review, and is regarded as creating some potentially perverse incentives for overly eager agreement by arbitrators with co-panelists in order to secure future appointments.

To be clear, I am not suggesting that Janis's model is literally how party-appointed arbitrators function, for several obvious reasons, including the fact that there are two party-appointed arbitrators, not just one. Moreover, they are not assigned a random and rotating role, but instead very intentionally and strategically chosen by the parties. I use Janis' suggestion as by analogy. Notwithstanding these differences, the analogy is strong.

By the same token, I am not arguing that Janis's proposal should change how party-appointed arbitrators operate or function. I am arguing instead that Janis's model is a more accurate understanding of how party-appointed arbitrators actually function than how we currently describe them. At their best, they function as a check against decision making by the majority that is not duly rigorous in considering the positions and arguments of the party who appointed that arbitrator.

Although I believe this is a powerful affirmative case for the function of party-appointed arbitrators, it still leaves open some important questions. One concern is: how does this idea of a party-appointed devil's advocate fit with our notions of impartiality? Isn't "an impartial devil's advocate" an oxymoron?

Part of the answer to this question is simply semantics. On the one hand, we know that even party-appointed arbitrators are not supposed to be "advocates". Although Janis was not contemplating lawyers when he came up with his terminology, he uses a lot of legal analogies, and some of them, particularly the term "devil's advocate", perhaps obscure the issue.

Another linguistic problem is that party-appointed arbitrators are supposed to be, somehow, neutral or "impartial". However, even though we use the same word - impartiality - to describe the 
obligations of a party-appointed arbitrator and an arbitral chairperson, that word cannot actually have the same meaning in the two contexts.

One signal they cannot mean the same thing is that there are different appointment procedures and standards. For example, party-appointed arbitrators are generally acknowledged, apart from the International Centre for Settlement of Investment Disputes (ICSID) Rules, as being able to share the nationality of the appointing party. Under most institutional rules, the chairperson cannot. This distinction between the acceptability of shared nationality signals that we have different expectations about what impartiality means as between these different categories of arbitrators.

Another example of how impartiality obligations are necessarily different for party-appointed arbitrators is that, as noted in the beginning, parties intentionally and directly choose their partyappointed arbitrators, subject only to challenges for conflicts of interest. As part of this process, while still somewhat controversial, several international sources confirm that parties may conduct interviews of party-appointed arbitrators, but not of arbitral chairpersons. How can an arbitrator deliberately chosen by, and potentially interviewed by, one party be impartial as an arbitrator in the same way as an arbitrator selected by both party-appointed arbitrators without any interviews?

While party selection of a decision maker seems at odds with impartiality, it is actually something that we do quite often in other contexts and by other means. Parties forum shop. We have various rules against forum shopping, but as we all know those rules are only partially effective because parties do as much as they can to try and control how their disputes are going to be heard and by whom. In the United States and in other systems that have civil law juries, or even in criminal cases, parties very intentionally pick people who are like themselves and are likely to be sensitive to, or reflective of, their concerns in the case. The idea of picking or having some input into the constitution of a tribunal is not as much of an anathema as sometimes suggested in the abstract when people are being critical of arbitration.

Nevertheless, the tripartite tribunal, with two party-appointed arbitrators does raise important concerns about fairness in the process of how party-appointed arbitrators are selected and appointed. If one side is interviewing their party-appointed arbitrator and the other side is not, the constitution of the tribunal is not fair.

One of the biggest problems regarding fairness, however, is the profound information asymmetries that exist and affect the selection process. What is even more disconcerting about these information asymmetries, as you may have already intuited, it that they are not random, hit or miss. These information asymmetries very much privilege insiders over outsiders. Large companies over smaller adversaries, (often) private investors over states, and large law firms over smaller regional firms or newcomers to international arbitration, have tremendous informational advantages. Asymmetries in the professional capacity of attorneys can also contribute and aggravate these information asymmetries, and I will come back to this point again in my conclusions about the future of international arbitration in New Zealand. 
Particularly for developing states in investment arbitration, informational and capacity asymmetries have been an important issue, in part because many developing countries are not able to retain outside counsel, or at least not to multinational law firms. They have delegated representation of cases involving hundreds of millions or billions of their taxpayer dollars to the attorney-general offices, who were often new to the process and lacked the networks that are essential in developing information, including about arbitrators.

If you have less-experienced counsel they do not know what questions to ask and do not have the network of colleagues to ask those questions about arbitrators. They operate at a significant strategic disadvantage. In addition, once you accept that each party should be able to maximise their opportunity in the appointment process of party-appointed arbitrators, this model heightens the importance of making sure that the chairperson is truly neutral.

Just as Janis had a proposed solution for groupthink, I have a proposed solution for informational asymmetries that can affect the fairness of arbitrator selection and appointment. The basic idea is to create an information resource about arbitrators that is equally accessible, comprehensive, substantive and reliable. Increasing access to information, including categories of information that are currently limited to arbitration insiders. I have called the project Arbitrator Intelligence. It is a non-profit start up that aims to level the playing field among participants, and promote greater transparency in the arbitrator selection process. Arbitrator Intelligence will also promote market-based accountability among arbitrators, and provide opportunities for new arbitrators to establish reputations and increase the likelihood of being selected. ${ }^{14}$

To accomplish these aims, Arbitrator Intelligence will develop three categories of information: public, semi-public and feedback. It will organise basic biographic information into individualised webpages for international arbitrators based on traditional forms of publicly available information.

A second category of information, which might be considered semi-public, is arbitral awards. Whenever an award is sought to be annulled or recognised or enforced, it is filed with a court. In many systems, court files, including their attachments, can be accessed and copied.

The most innovative, and delicate, aspect of the Arbitrator Intelligence would be a mechanism for providing feedback about arbitrators. The aim of this feature is to replicate that critical information that is currently gathered through ISO emails and accessible only to some parties. The aim is to solicit and consistently obtain constructive, reliable and useful feedback.

Some critics are concerned that Arbitrator Intelligence may simply be a new advertising space for international arbitrators or a "good news only" source. Other critics have noted concern that it

14 Arbitrator Intelligence <www.arbitratorintelligence.org>. At the time this presentation was made, Arbitrator Intelligence had not yet launched formally. Today, it is still in start-up phases, but as a result of the Law Foundation presentation, New Zealand has already been an important jurisdiction in terms of memberships and contributions. 
might be an arbitrator-related version of Wikipedia, or the equivalent of a grocery store "comment box" that acts as a receptacle for all rational and irrational gripes, or a tabloid that collects reckless and scintillating gossip.

To avoid these concerns, feedback will not be "open source", such as on eBay, Amazon or other online vendor sites. It will instead be solicited as responses to specific questions. Those questions will aim at the types of issues parties currently seek substantive information about through informal inquiries, such as the level of document production permitted by an arbitrator.

Arbitrator Intelligence undoubtedly raises a number of important practical and legal questions. Who would provide that feedback - counsel or parties? Should feedback be collected before or after an award is rendered? Could arbitrators themselves or arbitral institutions provide feedback? What about confidentiality? How would feedback avoid distortions by disgruntled losing parties and overly buoyant prevailing parties? Would feedback be publicly attributed to the person providing it? If not, how would contributors be accountable? How would Arbitrator Intelligence obtain arbitratorspecific information since most conduct is undertaken as a member of a three-person tribunal? How would confidentiality about the parties' dispute and arbitral proceedings be protected? Could Arbitrator Intelligence be potentially liable for defamatory or otherwise improper postings?

While these are difficult questions, they are not insurmountable obstacles. Editorial policies and procedures will be developed to answer these questions. Those policies and procedures, along with the content of the questionnaire for eliciting feedback, will be developed with input from an advisory board composed of various stakeholders. The two most important challenges for making this proposed solution work are: (1) collection of a broad base of reliable information; and (2) buyin from various segments of the arbitration community.

It is still a work in progress, and as a non-profit, work is incremental. Opportunities to present the idea, and the problems it will solve, to diverse and interested communities like this gathering are an important part of our work.

So with that background about selection of arbitrators, problems inherent in the process and a proposal to resolve some of those problems, the question becomes: what does this all mean for New Zealand?

Since I arrived in New Zealand, I have been asking: what is the role of international arbitration in New Zealand? It is difficult to determine the extent to which my concern over insiders versus outsiders applies to New Zealand because it does not fit very easily into either or those categories, right? On the one hand, New Zealand is, certainly on a per capita basis, dramatically overrepresented among the superstars of international arbitration. If you took a list of the top 100 international arbitration practitioners in the world, given the size of New Zealand, you have a radical over-representation of New Zealanders. 
On the other hand, New Zealand is both quite small and quite physically remote. If part of what determines insider status is an ability to be part of a cohesive group, just proximity and a related ability to hobnob at various conferences can be quite important.

Another reason why New Zealand is a unique and interesting example is its special role, not only in international arbitration but in international law. Here again, it seems to have a really outsized role because of its reputation for, because of its focus on, and its commitment to, various substantive issues. You would not expect a small island state to have the effect that it does on various important, topical international bodies and on international issues.

Given its role in public international law, and the fact that New Zealand is, essentially, an export economy dependent on international trade, combined with its reputation for excellence in education on private international law topics, perhaps an even more relevant question is why New Zealand is not even more important in the international arbitration community. It also raises the question about what might be the future of international arbitration in New Zealand.

It seems to me, even if a new visitor, that the future looks bright, both because of New Zealand's wealth of human and institutional resources, and its commitment to capitalise on those resources.

For example, I congratulate the Law Foundation for bringing Lucy Reed, a leading voice in the international arbitration community, here last year, and for sponsoring this event and other arbitration-related the events of this week. In these efforts, the Law Foundation, you bring an international arbitration person here to share ideas and exchange ideas, as I have been in various different groups and will continue to be doing throughout the week. But even beyond these local exchanges, I will take back with me wherever I go these very firm thoughts about New Zealand and its place in the world and the world of international arbitration, as I am sure Lucy did and as how others who follow surely will.

In addition, I have also learned more about Victoria University's, and Professor Butler's, excellent presence and her team's presence in the Vis Moot, and the fact that Auckland now, for the first year, has a team. Those are also important investments. The Vis requires a significant investment, especially to send students from New Zealand to Vienna. It is a huge investment, but one with a big payoff. Law firms notice which teams do well. In fact, law firms actually recruit out of the Vis Moot, which is quite extraordinary. The winners of the Vis Moot are announced to the international arbitration professional community, unlike any other moot competition I know of. What this means is that New Zealand students who go to Vienna and compete serve as very visible "ambassadors" for New Zealand and the strength of its education in international arbitration.

The sizable investment in the Vis Moot also yields dividends back here in New Zealand. Since I have been here, I have met a lot of young, international arbitration enthusiasts, many of whom are Vis Moot alums. These young lawyers are, in many instances, currently clerking for judges or beginning their careers in tangential areas. They still, however, as a result of their experience in the 
Moot, have an excitement about international arbitration that keeps them focused on any arbitrationrelated opportunity.

This group of young Vis alums joins another source of incredible wealth - the sizable number of New Zealanders who have gone off to have interesting careers and experiences, but many of whom migrate back to New Zealand. When they come back, they bring with them international arbitration experience and cases with them.

The last piece that I believe will continue to shape international arbitration here in New Zealand is scholarship. I know that David Williams together with Amokura Kawharu, and contributing authors Daniel Kalderimis, Anna Kirk and Campbell Walker, have written the first comprehensive work on arbitration in New Zealand. ${ }^{15}$ This exceptional work will put New Zealand on the shelves of international arbitration libraries everywhere and undoubtedly serve to increase interest and understanding about arbitration in New Zealand well beyond these islands and their vicinity.

If you add to Williams and Kawharu's work the excellent scholarship that is coming out of both Auckland and Victoria in international arbitration and related areas, they also help promote both New Zealand scholars in the international community and a New Zealand perspective on these issues.

Cumulatively, all these things together signal that, even if there hangs some mystery about why international arbitration has not entirely bloomed here in New Zealand, arbitration here is alive and well. It also seems reasonable to predict, based on these touchstones, that New Zealand will have an interesting role to play in the future of international arbitration, including being able to weigh in on some important decisions on how to make the process more fair going forward. Perhaps even with respect to selection of arbitrators.

With this, I have concluded my formal remarks and I thank you for your very kind attention.

15 David AR Williams and Amokura Kawharu Williams \& Kawharu on Arbitration (LexisNexis, Wellington, 2011). 